\title{
PENERAPAN MODEL COOPERATIVE LEARNING TIPE SCRAMBLE UNTUK MENINGKATKAN HASIL BELAJAR SISWA PADA PEMBELAJARAN IPS KELAS VI SEMESTER II SDN 1 PUTAT GROBOGAN
}

\author{
Hartoyo \\ SDN 1 Putat Grobogan
}

\begin{abstract}
This study aims to improve the ability of social studies learning outcomes in social studies learning in class VI SD Negeri 1 Putat through learning models Value Clarification Technique. This research is a classroom action research where researchers collaborate with colleagues as observers in conducting research. The research subjects were class VI SD Negeri 1 Putat students, as many as 20 students consisted of 14 male students and 6 female students. Learning outcomes of class VI students on social studies subjects increased from each action in each cycle, increasing student learning outcomes in class VI students from the results of the evaluation of the first cycle of students who completed as many as 14 people (70\%), in the second cycle to 19 people (95\%). This is evident from the results of evaluations of students who completed the KKM value of the total number of students as many as 20 people the results increased. Conclusion The use of scramble type cooperative learning model can improve the ability of social studies learning outcomes in social studies learning class VI SD Negeri 1 Putat.
\end{abstract}

Keywords: Ability of learning outcomes of IPS, Cooperative Learning, Scramble.

\begin{abstract}
ABSTRAK
Penelitian ini bertujuan untuk meningkatkan kemampuan hasil belajar IPS pada pembelajaran IPS di kelas VI SD Negeri 1 Putat melalui model pembelajaran Value Clarification Technique. Penelitian ini merupakan penelitian tindakan kelas dimana peneliti bekerja sama dengan teman sejawat sebagai observer pada pelaksanaan penelitian. Subjek penelitian adalah siswa kelas VI SD Negeri 1 Putat, sebanyak 20 siswa terdiri dari 14 siswa laki-laki dan 6 siswa perempuan. Hasil belajar siswa kelas VI pada mata pelajaran IPS terjadi peningkatan dari setiap tindakan dalam setiap siklusnya, peningkatan hasil belajar siswa pada siswa kelas VI dari hasil evaluasi siklus I siswa yang tuntas sebanyak 14 orang (70\%), pada siklus II menjadi 19 orang (95\%). Hal ini terbukti dari hasil evaluasi siswa yang tuntas nilai KKM dari jumlah keseluruhan siswa sebanyak 20 orang hasilnya meningkat. Kesimpulan penggunaan model model cooperative learning tipe scramble dapat meningkatkan kemampuan hasil belajar IPS pada pembelajaran IPS kelas VI SD Negeri 1 Putat
\end{abstract}

Kata Kunci : Kemampuan hasil belajar IPS, Cooperative Learning, Scramble.

\footnotetext{
${ }^{1)}$ Korespondensi : Hartoyo. SDN 1 Putat Grobogan

Email : Hartono1putat@yahoo.co.id
} 


\section{PENDAHULUAN}

Undang-undang Republik Indonesia nomor 20 Tahun 2003 tentang Sistem Pendidikan Nasional Indonesia pada Bab III Pasal 4 (dalam Syah, 2010: 1) menyatakan bahwa 'Pendidikan diselenggarakan dengan memberi keteladanan, membangun kemauan, dan mengembangkan kreativitas peserta didik dalam proses pembelajaran'. Selaras dengan pernyataan tersebut, dalam sebuah pembelajaran tidak hanya ketuntasan materi saja yang diperhatikan, melainkan bagaimana sebuah pembelajaran bisa memberikan keteladanan yang dapat membangun kreativitas siswa dan mengembangkannya dalam sebuah pembelajaran. Menurut Poerbakawatja (dalam Syah, 2010: 11), menyatakan bahwa: Pendidikan adalah usaha secara sengaja dari orang dewasa untuk dengan pengaruhnya meningkatkan si anak ke kedewasaan yang selalu diartikan mampu menimbulkan tanggung jawab moril dari segala perbuatannya. Sementara itu menurut Mudyahardjo (dalam Sagala, 2010: 3), bahwa: Pendidikan adalah segala pengalaman belajar yang berlangsung dalam segala lingkungan dan sepanjang hidup serta pendidikan dapat diartikan sebagai pengajaran yang diselenggarakan oleh sekolah sebagai lembaga pendidikan formal.

Berdasarkan pendapat yang telah dipaparkan, bahwa pendidikan adalah suatu usaha yang dilakukan secara sengaja untuk mengembangkan kemampuan diri dari yang tidak bisa menjadi bisa dan yang tidak tahu menjadi tahu yang disertai dengan perubahan tingkah laku yang lebih baik lagi. Pendidikan di selenggarakan dalam berbagai jenis yang terdiri dari pendidikan formal, dan nonformal.

Dalam pendidikan formal terdapat beberapa mata pelajaran yang semuanya penting untuk dipahami dan dikuasai oleh setiap siswa untuk mengembangkan berbagai aspek baik dari segi kognitif, afektif, dan psikomotornya demi menunjang ketercapaian tujuan pendidikan di Indonesia. Hal ini seharusnya sudah ditanamkan pada pendidikan yang paling dasar yaitu Sekolah Dasar. Di satuan pendidikan Sekolah Dasar, kurikulum yang digunakan adalah Kurikulum Tingkat Satuan Pendidikan (KTSP). Dimana KTSP memuat beberapa mata pelajaran yang harus diberikan kepada siswa, salah satunya yaitu mata pelajaran Ilmu Pengetahuan Sosial (IPS).

Menurut Saidihardjo (2005: 109) "Ilmu Pengetahuan Sosial bertujuan agar 
siswa mampu mengembangkan pengetahuan, sikap, dan keterampilan sosial, yang berguna bagi kemajuan dirinya sebagai individu maupun sebagai anggota di lingkungan masyarakat". Sementara itu, menurut Ischak (2005: 109) "pembelajaran IPS bertujuan membentuk warga negara yang berkemampuan sosial dan yakin akan kehidupannya sendiri ditengah-tengah kekuatan fisik dan sosial menjadi warga negara yang bertanggungjawab".

Berdasarkan pemaparan di atas, bahwa ilmu pengetahuan sosial mempelajari tentang bagaimana seorang manusia hidup dan bersosialisasi dalam lingkungan masyarakat dan bertujuan untuk mengembangkan siswa yang dapat bersosialisasi dalam lingkungan masyarakat dari segi pengetahuan, maupun sikapnya dalam hidup sebagai makhluk sosial yang menempatkan dirinya menjadi bagian dari anggota masyarakat dan warga negara. Maka dari itu, pada proses pembelajaran IPS diharapkan dapat dilaksanakan dengan baik. Proses pembelajarannya harus memberikan peluang kepada siswa agar berhasil dalam menguasai kompetensi dasar yang pada akhirnya dapat menjadi warga negara yang bertanggungjawab dalam lingkungan masyarakat. Menurut
Jihad dan Haris (2013: 12) menyatakan bahwa: Dalam proses pembelajaran, baik guru maupun siswa bersama-sama menjadi pelaku terlaksananya tujuan pembelajaran. Tujuan pembelajaran ini akan mencapai hasil yang maksimal apabila pembelajaran berjalan secara efektif. Sementara itu, menurut Wragg (dalam Jihad dan Haris, 2013: 4) menyatakan bahwa: Pembelajaran yang efekif adalah pembelajaran yang memudahkan siswa untuk mempelajari sesuatu yang bermanfaat seperti fakta, keterampilan, nilai, konsep, dan bagaimana hidup serasi dengan suatu hasil belajar yang diinginkan.

Maka dari itu, proses pembelajaran sebaiknya melibatkan siswa untuk berpartisipasi aktif adanya interaksi antara guru dan siswa untuk mencapai tujuan pembelajaran. Siswa yang berhasil dalam belajar adalah siswa yang dapat mencapai tujuan pembelajaran. Menurut Jihad dan Haris (2013: 14) "siswa yang berhasil dalam belajar adalah yang berhasil mencapai tujuan-tujuan pembelajaran". Sementara itu, menurut Sudjana (dalam Jihad dan Haris, 2013: 15) 'setelah melalui proses belajar maka siswa diharapkan dapat mencapai tujuan belajar yang disebut juga hasil belajar yaitu kemampuan yang dimiliki siswa setelah 
menjalani proses belajar'. Maka dari itu, dapat disimpulkan bahwa siswa setelah melaksanakan proses pembelajaran, diharapkan dapat mencapai tujuan belajar, dimana tujuan belajar ini merupakan hasil belajar siswa yang diharapkan. Selaras dengan pernyataan tersebut, menurut Hamalik (dalam Jihad dan Haris, 2013: 15) mengemukakan bahwa: Tujuan belajar adalah sejumlah hasil belajar yang menunjukkan bahwa siswa telah melakukan perbuatan belajar, yang umumnya melewati pengetahuan, keterampilan dan sikap-sikap yang baru, yang diharapkan dapat dicapai oleh siswa.

Untuk mendapatkan hasil belajar yang memuaskan dan sesuai dengan apa yang diharapkan, maka diperlukan sebuah proses pembelajaran yang dapat menunjang ketercapaian hasil belajar tersebut. Hal ini bisa dilihat dari sejauh mana keterlibatan siswa dapat terlaksana dengan baik dalam proses pembelajaran. Semakin besar keterlibatan siswa, maka semakin tinggi juga hasil belajar siswa yang dicapai.

Hasil observasi peneliti di SD Negeri 1 Putat, ditemukan beberapa permasalahan, khususnya di kelas VI pada mata pelajaran IPS, bahwa pembelajarannya di kelas tersebut guru menggunakan model pembelajaran satu arah yaitu dengan menggunakan metode ceramah. Sehingga siswa merasa mudah bosan dan cenderung kurang tertarik dalam mengikuti pembelajaran. Hal ini diperkuat berdasarkan hasil observasi ketika proses pembelajaran IPS berlangsung di kelas tersebut, yang menunjukan bahwa terdapat beberapa siswa yang cenderung kurang memperhatikan guru ketika menjelaskan materi pelajaran. Situasi proses pembelajaran yang kurang merangsang siswa untuk memiliki semangat dalam diri untuk belajar, sehingga hasil belajar siswa dalam mata pelajaran IPS cenderung rendah. Hal ini terlihat dari hasil nilai ulangan harian siswa pada mata pelajaran IPS cenderung rendah dibanding dengan mata pelajaran yang lain. Nilai Ketuntasan Kriteria Minimal (KKM) mata pelajaran IPS di sekolah tersebut 72, sedangkan nilai yang diperoleh siswa rata-rata di bawah 72 . Dari 25 orang siswa, hanya 10 (40\%) orang siswa yang mendapatkan nilai di atas KKM, sedangkan sisanya 15 $(60 \%)$ orang siswa mendapatkan nilai di bawah KKM.

Berdasarkan pemaparan di atas, diperlukan sebuah perubahan yang lebih baik lagi dalam segi penggunaan model pembelajaran yang dapat meningkatkan hasil belajar siswa terhadap mata 
pelajaran IPS. Terdapat beberapa model pembelajaran yang dapat digunakan dan efektif untuk meningkatkan hasil belajar siswa. Salah satu model pembelajaran yang dapat digunakan untuk meningkatkan hasil belajar yaitu dengan menggunakan model cooperative learning dimana siswa dapat belajar dan bekerja sama dengan temannya secara berkelompok. Salah satu dari model pembelajaran cooperative learning adalah scramble.

Menurut Shoimin (2014: 164) "pembelajaran scramble memungkinkan siswa untuk saling belajar sambil bermain, selain membangkitkan kegembiraan dan melatih keterampilan juga memupuk rasa solidaritas dan dapat mendorong siswa untuk maju”. Sementara itu Komalasari (2010: 84) berpendapat bahwa:

Pembelajaran scramble sebagai model pembelajaran yang mengajak siswa mencari jawaban terhadap suatu pertanyaan atau pasangan dari suatu konsep secara kreatif dengan cara menyusun huruf-huruf yang disusun secara acak sehingga membentuk suatu jawaban atau pasangan konsep.

Dari pendapat tersebut bahwa model pembelajaran kooperatif tipe scramble merupakan suatu model pembelajaran yang dapat membangun kreatif dapat menciptakan suasana yang menggembirakan dan dapat mendorong siswa untuk mencari tahu jawaban dari pertanyaan yang diberikan, sehingga siswa terlibat dalam proses pembelajaran. Dengan demikian ketika siswa sudah terlibat aktif dalam pembelajaran siswa akan fokus dalam pembelajaran, dan membuat siswa dapat memahami materi yang disampaikan oleh guru. Maka dari itu, dapat disimpulkan bahwa pembelajaran dengan menggunakan model cooperative learning tipe srcamble dapat meningkatkan hasil belajar siswa, karena siswa bisa terlibat aktif dalam pembelajaran, pembelajaran yang tidak monoton memungkinkan dapat memahami materi yang disampaikan dengan baik.

Adapun tujuan penelitian yang ingin dicapai oleh penulis dalam penelitian ini adalah untuk mengetahui penerapan model cooperative learning tipe scramble dalam pembelajaran IPS pada siswa kelas VI di SD Negeri 1 Putat serta untuk mengetahui hasil belajar siswa pada pembelajaran IPS pada siswa kelas VI SD Negeri 1 Putat setelah menggunakan model cooperative learning tipe Scramble. 


\section{METODE PENELITIAN}

Dalam penelitian ini peneliti menggunakan metode Penelitian Tindakan Kelas (PTK). Model penelitian yang digunakan dalam penelitian ini mengacu pada model siklus Kemmis $\mathrm{S}$, dan Mc. Taggert R (dalam Arikunto, 2010: 74). Dengan beberapa pertimbangan dan alasan peneliti menentukan waktu penelitian selama 3 bulan yaitu pada bulan Maret sampai bulan Mei 2018. Dimulai dari penyusunan instrumen, pengumpulan data, analisis data dan penyusunan laporan penelitian yang akan dilakukan pada bulan Maret-Mei 2018.

Kegiatan penelitian dilaksanakan di kelas VI SD Negeri 1 Putat Kecamatan Purwodadi Kabupaten Grobogan tahun 2017/2018 sebanyak 20 siswa. Penelitian dilakukan di SD Negeri 1 Putat karena berdasarkan observasi awal peneliti ditemukan masalah dalam pembelajaran di sekolah tersebut yaitu rendahnya hasil belajar siswa di kelas VI pada mata pelajaran IPS yang diperoleh dari hasil ulangan harian IPS yang tidak memenuhi KKM. Sehingga peneliti melakukan PTK untuk meningkatkan hasil belajar siswa pada mata pelajaran IPS materi Peranan Indonesia pada era globalisasi dan dampak positif serta negatifnya terhadap keidupan bangsa Indonesia .
Subjek penelitian dilakukan di SD Negeri 1 Putat Kecamatan Purwodadi Kabupaten Grobogan kelas VI sebanyak 20 siswa, yang terdiri atas 14 siswa laki-laki dan 6 siswa perempuan dengan wali kelas Hartoyo.

Dalam penelitian ini peneliti menggunakan sumber primer dengan kuesioner yang diberikan kepada siswa SD Negeri 1 Putat di kelas VI dengan banyaknya data sesuai dengan jumlah siswa yaitu 20. Sementara itu sumber data sekunder dalam penelitian ini menggunakan dokumen-dokumen resmi untuk memperkuat penelitian yang berupa catatan-catatan siswa, dan data-data nilai siswa.

\section{HASIL DAN PEMBAHASAN}

Pada saat awal sebelum dilaksanakan penelitian pembelajaran IPS di kelas VI SD Negeri 1 Putat di temukan beberapa masalah dalam proses pembelajaran, yang menyebabkan hasil belajar siswa tidak memenuhi nilai KKM yaitu 72. Berdasarkan tes awal, dari seluruh siswa yang berjumlah 20 orang hanya 9 orang (45\%) siswa yang tuntas dari nilai KKM dan 11 orang (55\%) siswa yang belum tuntas dari nilai KKM. Hal ini menunjukkan bahwa hasil belajar siswa pada mata pelajaran IPS khususnya materi 
peranan Indonesia pada era globalisasi dan dampak positif serta negatifnya terhadap keidupan bangsa Indonesia masih sangat rendah. Setelah mengkaji dan mendiskusikannya dengan guru kelas VI faktor yang menyebabkan rendahnya hasil belajar siswa yaitu penggunaan model yang cenderung menggunakan metode ceramah, serta penggunaan media yang jarang digunakan. Sehingga siswa menganggap bahwa pelajaran IPS itu membosankan.

Berdasarkan hal tersebut, untuk meningkatkan hasil belajar siswa pada mata pelajaran IPS khususnya pada materi peranan Indonesia pada era globalisasi dan dampak positif serta negatifnya terhadap keidupan bangsa Indonesia peneliti memutuskan utuk melakukan perbaikan pembelajaran yaitu dengan menerapkan model cooperative learning tipe scramble yang menekankan siswa untuk berdiskusi, sehingga pembelajaran tercipta dengan menarik dan menyenangkan. Diharapkan dengan diterapkannya model tersebut dapat meningkatkan hasil belajar siswa kelas VI SD Negeri 1 Putat pada mata pelajaran IPS.

Peneliti dalam melaksanakan model cooperative learning tipe scramble ini menggunakan media berupa gambar yang dapat dilihat secara visual oleh siswa, sehingga siswa lebih memahami dan membangun pengetahuan siswa lebih luas akan materi yang disampaikan. Peneliti membagi siswa ke dalam kelompok, hal ini dilaksanakan untuk mendiskusikan mengenai materi peranan Indonesia pada era globalisasi dan dampak positif serta negatifnya terhadap keidupan bangsa Indonesia dengan model scramble yaitu dalam pengerjaannya siswa menjawab pertanyaan yang diberikan yang telah disediakan alternatif jawaban yang di acak susunan hurufnya, sehingga siswa diminta untuk menyusun huruf tersebut menjadi sebuah kata yang benar.

Pelaksanaan proses pembelajaran tersebut terlihat semua siswa merasa semangat dan antusias untuk melaksanakan pembelajaran. Meskipun pada awalnya siswa terlihat asing terhadap proses pembelajarannya, dan tidak mengetahui bagaimana cara mengerjakannya, namun setelah peneliti menggunakan media gambar mengenai peranan Indonesia pada era globalisasi dan dampak positif serta negatifnya terhadap keidupan bangsa Indonesia siswa menjadi lebih tertarik dan rasa ingin tahu siswa muncul untuk melaksanakan pembelajaran dengan baik. Akan tetapi, dalam pelaksanaan model scramble ini peneliti mengalami beberapa hambatan, yaitu: 
sulitnya mengkondisikan siswa, tingkat pengetahuan dan pemahaman siswa yang tergolong masih rendah sehingga peneliti harus lebih mencari teknik mengajar yang dapat membangun rasa antusias siswa lebih tinggi, dan kondisi kelas yang sempit sehingga kurang membantu terciptanya proses pembelajaran yang nyaman.

Berdasarkan hambatan yang ditemukan tersebut, maka peneliti mendiskusikan dan meminta saran mengenai hal tersebut dengan guru kelas VI. Atas saran dan dorongan yang diberikan oleh guru kelas VI, peneliti akhirnya dapat mengatasi hambatan tersebut, adanya peningkatan dalam pelaksanaan model scramble ini dari mulai siklus I, dan II. Peneliti dapat mengkondisikan siswa dengan baik, dapat membangun antusias siswa untuk mengikuti pembelajaran dengan baik, dan materi yang dipelajari siswa tersampaikan dengan baik.

Adapun rincian dari hasil evaluasi yang diberikan pada siswa dari setiap tindakan pada siklus I, dan II yaitu sebagai berikut :

\section{Tindakan I Siklus I}

Pada tindakan I siklus I hasil yang diperoleh yaitu aktivitas guru dalam penerapan model cooperative learning tipe scramble yaitu dari 21 point yang tersedia diperoleh 17 point yang terlaksana dan aktivitas siswa dari 20 point yang tersedia diperoleh 15 point yang terlaksana. Pada tindakan I peneliti memberikan tes evaluasi di akhir tindakan, hasil evaluasi diperoleh siswa yang tuntas mencapai $50 \%$ dari seluruh jumlah siswa kelas VI sebanyak 20 orang. Pada tindakan I ini hasil belajar siswa terhadap materi masih belum memenuhi indikator keberhasilan siswa yang ditetapkan yaitu $85 \%$ dari seluruh siswa kelas VI yang berjumlah 20 orang harus tuntas di atas nilai Kriteria Ketuntasan Minimal (KKM) mata pelajaran IPS yaitu 72 .

\section{Siklus I Tindakan II}

Pada Siklus I Tindakan II hasil yang diperoleh yaitu aktivitas guru dalam penerapan model cooperative learning tipe scramble yaitu dari 21 point yang tersedia diperoleh 18 point yang terlaksana dan aktivitas siswa yaitu dari 20 point yang tersedia diperoleh 16 point yang terlaksana. Pada tindakan II peneliti memberikan tes evaluasi di akhir tindakan. Pada tindakan II hasil evaluasi siswa yang tuntas 14 orang (70\%) dari seluruh jumlah siswa kelas VI sebanyak 20 orang. Akan tetapi, pada tindakan II ini hasil belajar siswa masih kurang baik karena masih jauh dari indikator keberhasilan siswa yang 
ditetapkan yaitu $85 \%$ dari seluruh jumlah siswa yang harus tuntas di atas nilai KKM.

\section{Siklus II Tindakan I}

Pada Siklus II Tindakan I hasil yang diperoleh yaitu aktivitas guru dalam penerapan model cooperative learning tipe scramble yaitu dengan rincian dari 21 point yang tersedia diperoleh 19 point yang terlaksana dan aktivitas siswa yaitu dari 20 point yang tersedia diperoleh 16 point yang terlaksana. Pada tindakan I peneliti memberikan tes evaluasi di akhir tindakan, hasil evaluasi diperoleh siswa yang tuntas mencapai 16 orang $(80 \%)$ dari seluruh jumlah siswa kelas VI sebanyak 20 orang. Pada tindakan I ini hasil belajar siswa terhadap materi masih belum memenuhi indikator keberhasilan siswa yang ditetapkan yaitu $85 \%$ dari seluruh siswa kelas VI yang berjumlah 20 orang harus tuntas di atas nilai Kriteria Ketuntasan Minimal mata pelajaran IPS yaitu 72 .

\section{Siklus II Tindakan II}

Pada Siklus II Tindakan II hasil yang diperoleh yaitu aktivitas guru dalam penerapan model cooperative learning tipe scramble yaitu dari 21 point yang tersedia diperoleh 20 point yang terlaksana dan aktivitas siswa yaitu dari 20 point yang tersedia diperoleh 19 point yang terlaksana. Pada tindakan II peneliti memberikan tes evaluasi di akhir tindakan. Pada tindakan II hasil evaluasi siswa yang tuntas 19 orang (95\%) dari seluruh jumlah siswa kelas VI sebanyak 20 orang. Akan tetapi, pada tindakan II ini hasil belajar siswa baik karena sudah lebih dari indikator keberhasilan siswa yang ditetapkan yaitu $85 \%$ dari seluruh jumlah siswa yang harus tuntas di atas nilai KKM.

Model Cooperative Learning Tipe Scramble Dapat Meningkatkan Hasil Belajar Siswa.

Tabel 1. Peningkatan Siklus PTK

\begin{tabular}{|l|l|l|l|l|l|}
\hline No & Siklus & Tuntas & Tidak Tuntas & Tuntas (\%) & Belum Tuntas (\%) \\
\hline 1 & Data Awal & 9 & 11 & $\mathbf{4 5 \%}$ & $55 \%$ \\
\hline 2 & Siklus I Tindakan I & 10 & 10 & $50 \%$ & $50 \%$ \\
\hline 3 & Siklus I Tindakan II & 14 & 6 & $70 \%$ & $30 \%$ \\
\hline 4 & Siklus II Tindakan I & 16 & 4 & $80 \%$ & $20 \%$ \\
\hline 5 & Siklus II Tindakan II & 19 & 1 & $95 \%$ & $5 \%$ \\
\hline
\end{tabular}

Berdasarkan data di atas dapat dilihat bahwa setelah diterapkannya model cooperative learning tipe scramble terjadi peningkatan hasil belajar siswa di kelas VI SD Negeri 1 Putat dari data awal, siklus I, sampai siklus II sebanyak 50\%. Angka 
tersebut (50\%) didapat dari hasil penjumlahan peningkatan dari hasil data awal ke siklus I sebanyak 25\%, dari siklus I ke siklus II sebanyak $25 \%$ jadi total peningkatan 50\%. Serta terjadinya hipotesis tindakan dalam penelitian ini membuktikan bahwa penerapan model cooperative learning tipe scramble dapat meningkatkan hasil belajar siswa kelas VI SD Negeri 1 Putat pada mata pelajaran IPS khususnya pada materi peranan Indonesia pada era globalisasi dan dampak positif serta negatifnya terhadap keidupan bangsa Indonesia. Hal ini selaras dengan pendapat Hanafiah (dalam rachmawati, 2011: 8) 'model pembelajaran scramble bersifat aktif, siswa dituntut aktif bekerja sama serta bertanggungjawab terhadap kelompoknya untuk menyelesaikan kartu soal guna memperoleh poin dan diharapkan dapat meningkatkan kebersamaan siswa'. Maka dari itu dengan adanya partisipasi aktif dari siswa untuk bekerjasama dalam menyelesaikan tugas kelompok, siswa memiliki dorongan dan minat yang kuat untuk belajar, sehingga hasil belajar siswa pun akan meningkat.

\section{PENUTUP}

\section{Simpulan}

Hasil belajar siswa kelas VI pada mata pelajaran IPS setelah menggunakan model cooperative learning tipe scramble meningkat, hal ini terbukti dari hasil data awal yang diberikan peneliti dari seluruh jumlah siswa kelas VI 20 orang hanya 9 orang $(45 \%)$ siswa yang tuntas dari nilai KKM mata pelajaran IPS yaitu 72. Akan tetapi setelah peneliti menggunakan model cooperative learning tipe scramble terjadi peningkatan dari setiap tindakan dalam setiap siklusnya, peningkatan hasil belajar siswa pada siswa kelas VI dari hasil evaluasi siklus I siswa yang tuntas sebanyak 14 orang (70\%), pada siklus II menjadi 19 orang $(95 \%)$. Hal ini terbukti dari hasil evaluasi siswa yang tuntas nilai KKM dari jumlah keseluruhan siswa sebanyak 20 orang hasilnya meningkat. 


\section{DAFTAR PUSTAKA}

Arikunto, S. (2010). Prosedur Penelitian Suatu Pendekatan Praktik. Jakarta: Rineka Cipta.

Dimyati dan Mudjiono. (2015). Belajar dan Pembelajaran. Jakarta: Rineka Cipta.

Gunawan, R. (2011). Pendidikan IPS Filosofis, Konsep, dan Aplikasi. Bandung: Alfabeta.

Huda, M. (2014). Model-Model Pengajaran dan Pembelajaran. Yogyakarta: Pustaka Pelajar.

Ischak, S.U. dkk. (2005). Pendidikan IPS di SD. Jakarta: Universitas Terbuka.

Isjoni. (2007). Cooperative Learning (Efektifitas Pembelajaran Kelompok). Pekan Baru: Alfabeta.

Jihad, A dan Haris, A. (2013). Evaluasi Pembelajaran. Yogyakarta: Multi Presindo.

Komalasari, K. (2010). Pembelajaran Konstekstual Konsep dan Aplikasi. Bandung: PT. Refika Aditama.

Purwanto. (2011). Evaluasi Hasil Belajar. Yogyakarta: Pustaka Pelajar.

Rachmawati. (2010). Strategi Pengembangan Kreativitas. Jakarta: Kencana.

Rohmiyati, E. (2013). Penerapan Strategi Pembelajaran Scramble Untuk Meningkatkan Motivasi Dan Hasil Belajar Siswa Dalam Pembelajaran Matematika. Jurnal Universitas Muhammadiyah. Surakarta: Tidak Diterbitkan.

Sagala, S. (2010). Konsep dan Makna Pembelajaran. Bandung: Alfabeta.

Saidihardjo. (2005). Konsep Dasar Ilmu Pengetahuan Sosial. Yogyakarta: Depdiknas.

Sanjaya, W. (2009). Strategi Pembelajaran Berorientasi Standar Proses Pendidikan. Jakarta: Prenada Media.

Sapriya. (2009). Konsep Dasar IPS. Bandung: UPI PRESS.

Shoimin, A. (2014). 68 Model Pembelajaran Inovatif Dalam Kurikulum 2013. Yogyakarta: AR-RUZZ MEDIA.

Slameto (2003). Belajar dan Faktor-faktor yang Mempengaruhinya. Jakarta: Rineka Cipta.

Solihatin, E. (2011). Cooperative Learning. Jakarta: PT. Bumi Aksara.

Solihatin dan Raharjo. (2008). Cooperative Learning Analisis Model Pembelajaran IPS. Jakarta: Bumi Aksara.

Somantri, N. (2001). Menggegas Pembaharuan Pendidikan IPS. Bandung: Remaja Rosda Karya. 
Sugiyono. (2011). Metode Penelitian Kualitatif Dan R \& D. Bandung: Alfabeta.

Sukmadinata, N. S. (2005). Landasan Psikologi Proses Pendidikan. Bandung: PT Remaja Rosdakarya.

Suryosubroto, et al. (2004). Proses Belajar Mengajar di Sekolah. Jakarta: Rineka Cipta.

Syah, M. (2010). Psikologi Pendidikan. Bandung: PT. Remaja Rosdakarya.

Trianto. (2010). Mendesain Model Pembelajaran Inovatif-Progresif Konsep Landasan, dan Implementasinya Pada Kurikulum Tingkat Satuan Pendidikan. Jakarta: Kencana Prenada Media Group.

Wriatmadja, R. (2005). Metode Penelitian Kelas. Bandung: Remaja Rosdakarya. 